\title{
hsa-miR-141 downregulates TM4SF1 to inhibit pancreatic cancer cell invasion and migration
}

\author{
LIJIAN XU ${ }^{1,2 *}$, QIANG $\mathrm{LI}^{2 *}$, DONG XU ${ }^{3}$, QINGGUANG WANG ${ }^{1}$, YONG AN ${ }^{2}$, \\ QING DU ${ }^{2,4}$, JINGJING ZHANG ${ }^{2,4}$, YI ZHU ${ }^{2,4}$ and YI MIAO ${ }^{2,5}$ \\ ${ }^{1}$ Department of General Surgery, The Second Affiliated Hospital of Nanjing Medical University, Nanjing 210018; \\ ${ }^{2}$ Department of General Surgery, The First Affiliated Hospital of Nanjing Medical University, Nanjing 210029; \\ ${ }^{3}$ Department of General Surgery, Gaochun People's Hospital, Nanjing 211300; ${ }^{4}$ Jiangsu Province Academy \\ of Clinical Medicine, Institute of Tumor Biology, Nanjing 210029; ${ }^{5}$ Center for Pancreatic Surgery, \\ The First Affiliated Hospital of Nanjing Medical University, Nanjing 210029, P.R. China
}

Received September 4, 2013; Accepted October 22, 2013

DOI: 10.3892/ijo.2013.2189

\begin{abstract}
Expression of the transmembrane-4-L-six-family-1 (TM4SF1) is high in human pancreatic cancer cells, but the underlying mechanism remains unclear. In this study, we aimed to identify and characterize microRNAs that regulate TM4SF1 expression in PC cells. Western blot analysis and quantitative polymerase chain reaction were used to detect TM4SF1 and hsa-miR-141 levels in four PC cell lines. SW1990 and BxPc-3 cells were transfected with the inhibitor miR-141, the inhibitor negative control, the miR-141 mimic and the mimic negative control; and cell invasion, migration, proliferation, cell cycle progression and apoptosis were detected by Transwell, MTT and flow cytometry assays, respectively. The miR-141 levels negatively correlated with the TM4SF1 protein levels in PC cells. The TM4SF1 protein levels were lower in the 141M group but higher in the 141I group, although the TM4SF1 mRNA levels had no significant changes, compared to the negative controls. Luciferase assays demonstrated that hsa-miR-141 directly targeted the 3'-untranslated region of the TM4SF1 gene. In addition, miR-141 downregulated TM4SF1 expression to inhibit invasion and migration of PC cells but had no effects on cell proliferation, cell cycle progression or apoptosis. TM4SF1 is a direct target of miR-141. Our findings that TM4SF1 expression was inhibited by miR-141 provide new insights into the oncogenic mechanism of TM4SF1 and suggest that miR-141 represents a novel molecular target for PC therapy.
\end{abstract}

Correspondence to: Dr Yi Miao, Center for Pancreatic Surgery, The First Affiliated Hospital of Nanjing Medical University, 300 Guangzhou Road, Nanjing 210029, Jiangsu, P.R. China

E-mail: miaoyi@njmu.edu.cn

${ }^{*}$ Contributed equally

Key words: hsa-miR-141, TM4SF1, pancreatic cancer, migration, invasion

\section{Introduction}

Pancreatic cancer (PC) is one of the most lethal malignant diseases with a poor prognosis. PC is the fourth leading cause of cancer-related deaths in Western countries and has the lowest patient survival rate among all solid cancers. It has been estimated that 43,920 people were newly diagnosed with PC in 2012 (1). Although great efforts have been made in PC treatment using surgery, radiation therapy and chemotherapy, the 5-year survival rate of PC patients is still disappointing. Therefore, it is important to explore the molecular mechanisms that regulate PC development in order to develop effective therapies for PC.

Transmembrane-4-L-six-family-1 (TM4SF1), a small $22 \mathrm{kDa}$ four-transmembrane-domain protein also known as L6-Ag, is a surface protein highly expressed in human lung, breast, colon, ovarian, renal and prostate carcinomas, and it is weakly expressed in normal vascular endothelium (2). Due to its unique expression pattern, TM4SF1 has attracted much attention as a therapeutic target for monoclonal antibody-based cancer therapy (2). TM4SF1 belongs to a distinct family that includes five other structurally similar proteins: TM4SF4/IL-TMP, TM4SF5/L6H, TM4SF18/L6D, TM4SF19/OCTM4 and TM4SF20/TCCE518 (3). TM4SF1 has been shown to be associated with the growth, motility, invasion and metastasis of tumor cells (4-7). In particular, recent studies have shown that TM4SF1 is highly expressed in PC tissues and cell lines and that downregulation of TM4SF1 can decrease migration, invasion and chemoresistance of PC cells in vitro; increase the effectiveness of gemcitabine treatment; and inhibit tumor angiogenesis and metastasis in orthotopic tumor models in vivo (8). However, the molecular mechanisms that regulate TM4SF1 expression and function in PC remain unclear.

MicroRNAs (miRNAs) are a new class of endogenous, non-coding and short (19-24 nucleotides) single-stranded RNAs. miRNAs regulate gene expression by binding to the 3'-untranslated region (UTR) of the target gene leading to either downregulation of the mRNA transcript or inhibition of the protein translation process (9). miRNAs can regulate many cellular processes, such as apoptosis, cell cycle progression, 
proliferation, differentiation, invasion and migration, and either promote or inhibit tumorigenesis, depending on the genes they target and their differential expression in normal and cancer tissues (10-17).

hsa-miR-141, a member of the miR-200 family, is overexpressed in ovarian cancer, colorectal cancer, thyroid papillary carcinoma, pancreatic ductal adenocarcinoma, nasopharyngeal carcinoma, prostate tumor, cholangiocarcinoma and endometrial carcinoma, but it is downregulated in gastric cancer, renal cell carcinoma and breast cancer (18-28). These results lead to a controversial issue regarding the function of hsa-miR-141 in cancer progression.

In this study, we first investigated the correlation between the expression level of TM4SF1 and miR-141 in PC cells. Next, we demonstrated whether TM4SF1 is a direct target of miR-141. In addition, we determined whether the miR-141 mimic could affect invasion, migration, cell proliferation, cell cycle progression or apoptosis of PC cells.

\section{Materials and methods}

Cell culture. The human PC cell lines SW1990, PANC-1, BxPC-3 and CFPAC-1 cells were obtained from the Shanghai Cell Bank (Shanghai, China) and cultured in Dulbecco's modified Eagle's medium (DMEM, Wisent, St. Bruno, QC, Canada) supplemented with $10 \%$ fetal bovine serum (FBS, Wisent), $2 \mathrm{mM}$ glutamine, $100 \mu \mathrm{g} / \mathrm{ml}$ penicillin, and $100 \mu \mathrm{g} / \mathrm{ml}$ streptomycin in a humidified chamber at $37^{\circ} \mathrm{C}$ with $5 \% \mathrm{CO}_{2}$.

miRNAs transfection. Inhibitor miR-141 (141I), the inhibitor negative control (141I-NC), the miR-141 mimic (141M) and the mimic negative control (141M-NC) were designed and synthesized by GenePharma (Shanghai, China). SW1990 and $\mathrm{BxPc}-3$ cells were seeded in 6-well plates at a density of $50 \%, 24 \mathrm{~h}$ later the cells were transfected with miRNAs using Lipofectamine 2000 (Invitrogen, Carlsbad, CA, USA) following the manufacturer's instructions.

Quantitative real-time polymerase chain reaction ( $q R T-P C R)$. Total RNA was extracted from SW1990 and BxPc-3 cells by using TRIzol (Invitrogen). Primescript RT Reagent (Takara, Dalian, China) was used to synthesize cDNA. qRT-PCR was performed using SYBR-Green (Takara) on a 7500 Real-Time PCR System (Applied Biosystems, Foster City, CA, USA). The primers were as follows: TM4SF1 forward, 5'-ACCACTATG TCTTGATTCCCTC-3'; and reverse, 5'-ATTGTGGCTCTG TCCTGGGT-3'; GAPDH forward, 5'-TCACCCACACTGTG CCCATCTACGA-3'; and reverse, 5'-CAGCGGAACCGC TCATTGCCAATGG-3'; hsa-miR-141 forward, 5'-CGCTAA CACTGTCTGGTAAAG-3'; and reverse, 5'-GTGCAGGGT CCGAGGT-3'; U6 forward, 5'-ATTGGAACGATACAGAGA AGATT-3'; and reverse, 5'-GGAACGCTTCACGAATTTG-3'. The conditions were as follows: $95^{\circ} \mathrm{C}$ for $3 \mathrm{~min} ; 35$ cycles of $94^{\circ} \mathrm{C}$ for $30 \mathrm{sec}, 60^{\circ} \mathrm{C}$ for $30 \mathrm{sec}$ and $72^{\circ} \mathrm{C}$ for $30 \mathrm{sec}$; and $72^{\circ} \mathrm{C}$ for $5 \mathrm{~min}$. GAPDH mRNA and U6 were used as internal controls for determining the relative expression level of TM4SF1 mRNA and hsa-miR-141, respectively. The comparative $\Delta \Delta \mathrm{Ct}$ method was used to calculate relative expression levels of mRNAs and miRNAs, and the fold changes were analyzed by $2^{-\Delta \Delta \mathrm{Ct}}$.
Western blot analysis. Total protein was extracted from SW1990 and BxPc-3 cells using RIPA buffer supplemented with $1 \%$ phenylmethylsulfonyl fluoride (PMSF), and the protein concentration was estimated using a BCA kit (Keygen, Nanjing, China). Protein was separated by $12 \%$ sodium dodecyl sulfate polyacrylamide gel electrophoresis (SDS-PAGE) and transferred to poly vinylidene difluoride(PVDF) membranes. The membranes were blocked in Tris-buffered saline (TBS) with 5\% non-fat dry milk at $4^{\circ} \mathrm{C}$ for $15 \mathrm{~h}$ then incubated with primary antibodies against TM4SF1 (Abcam, Cambridge, MA, USA) or GAPDH (Beyotime, Jiangsu, China) at $4^{\circ} \mathrm{C}$ overnight. Membranes were incubated with anti-rabbit (or mouse) IgG-horseradish peroxidase-conjugated secondary antibody (Santa Cruz Biotechnology, Santa Cruz, CA, USA) for $2 \mathrm{~h}$ at room temperature, washed three times, developed with an electrochemiluminescence kit (Pierce, Rockford, IL, USA), and exposed to X-ray film to visualize the images. GAPDH served as a loading control.

Luciferase reporter assay. Four oligonucleotides corresponding to the 3'UTR of TM4SF1 were synthesized as follows: wild-type forward, 5'-CTAGATAAAGACTGGCATCTTCACAGGAT GTCAGTGTTTAAATTTAGTAGGCCGG-3'; and reverse, 5'-CCTACTAAATTTAAACACTGACATCCTGTGAAGAT GCCAGTCTTTAT-3'; and mutant-type forward, 5'-CTAGAT AAAGACTGGCATCTTCACAGGATGTTGATGCTTAAA TTTAGTAGGCCGG-3'; and reverse, 5'-CCTACTAAATTT AAGCATCAACATCCTGTGAAGATGCCAGTCTTTAT-3'. The oligonucleotides were cloned into the Xbal site of the pGL3 luciferase reporter gene (Promega, Madison, WI, USA) to generate pGL3-TM4SF1-3'UTR and pGL3-TM4SF13'UTR-mut vector. SW1990 and BxPc-3 cells were cultured in 24-well plates and co-transfected with $200 \mathrm{ng}$ of pGL3-TM4SF1 or pGL3-TM4SF1-mut and $20 \mathrm{ng}$ of pRL-SV40 (Promega) containing Renilla luciferase and $20 \mathrm{pmol}$ of $141 \mathrm{M}$ or $141 \mathrm{NC}$. At $48 \mathrm{~h}$ after transfection, cells were collected and luciferase activity was measured by using a Dual-Luciferase Reporter assay kit (Promega) following the manufacturer's instructions. All experiments were repeated three times.

Cell invasion and migration assay. Invasion and migration of cells were measured by a Matrigel invasion chamber assay, using a chamber of $6.5 \mathrm{~mm}$ in diameter with $8-\mu \mathrm{m}$ pore size Transwell chambers (Corning, Corning, NY, USA). SW1990 and $\mathrm{BxPc}-3$ cells were seeded into the upper chamber $\left(1.0 \times 10^{5}\right.$ cells per Transwell) pre-coated with $1 \mathrm{mg} / \mathrm{ml}$ Matrigel for the invasion assay or without Matrigel for the migration assay, and the bottom wells were filled with $500 \mu \mathrm{l}$ of $10 \%$ FBS-DMEM. After incubation for $24 \mathrm{~h}$ at $37^{\circ} \mathrm{C}$, non-invading or non-migrating cells were removed with cotton swabs, and cells that had invaded or migrated to the underside of the membrane were stained with $0.1 \%$ crystal violet for $15 \mathrm{~min}$ at $37^{\circ} \mathrm{C}$. Then, the membranes were washed with phosphate-buffered saline (PBS), and the invaded or migrated cells were counted under an inverted microscope. All experiments were carried out in triplicate.

Cell proliferation assay. SW1990 and BxPc-3 cells were seeded in 96-well culture plates (Costar, Cambridge, UK) at a density of $2 \times 10^{3}$ cells/well, $24 \mathrm{~h}$ later the cells were transfected with miRNAs, and $48 \mathrm{~h}$ later cell proliferation was detected by using 
$\mathbf{A}$
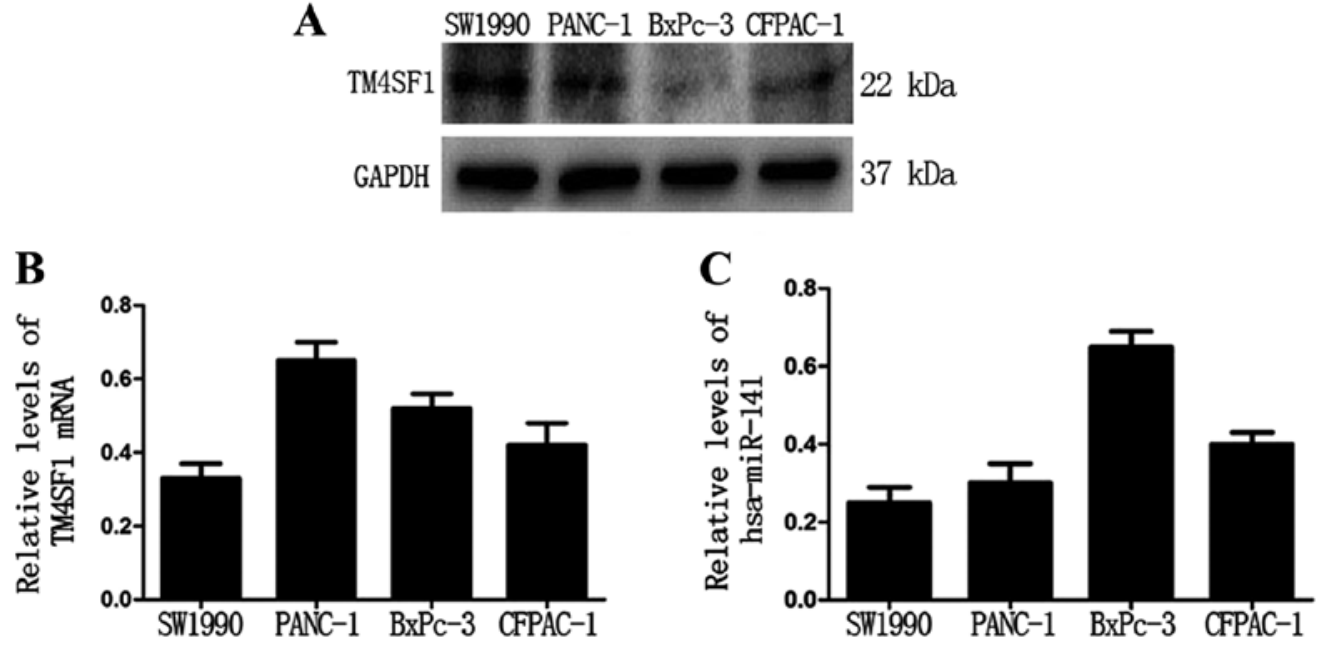

Figure 1. Relative expression levels of miR-141 and TM4SF1 in four PC cell lines. (A) Western blot analysis of the TM4SF1 protein level. Shown are representative blots from three independent experiments. GAPDH was used as a loading control. (B) The TM4SF1 mRNA level was detected by qPCR and normalized by GAPDH mRNA. (C) The miR-203 level was detected by qPCR and normalized to U6.
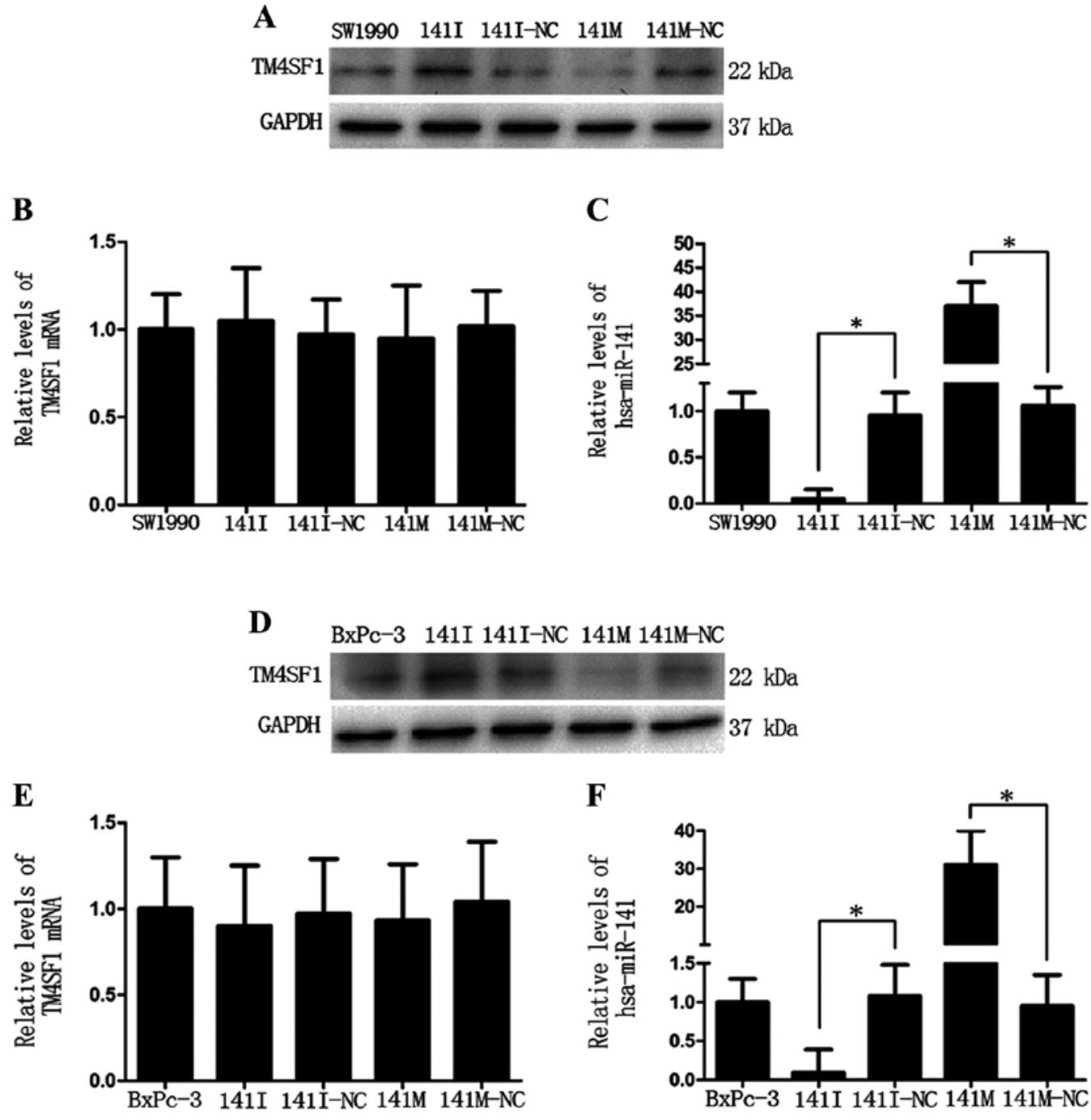

Figure 2. miR-141 inhibits TM4SF1 protein expression. Cells were transfected as indicated, $48 \mathrm{~h}$ later the cells were collected and subjected to western blot and qPCR analyses. (A and D) Western blot analysis of the TM4SF1 protein level. Shown are representative blots from three independent experiments. GAPDH was used as a loading control. (B and E) The TM4SF1 mRNA level was analyzed by qRT-PCR and normalized to GAPDH mRNA. (C and F) The hsa-miR-141 level was detected by qPCR and normalized to U6. ${ }^{*} \mathrm{P}<0.05$. 

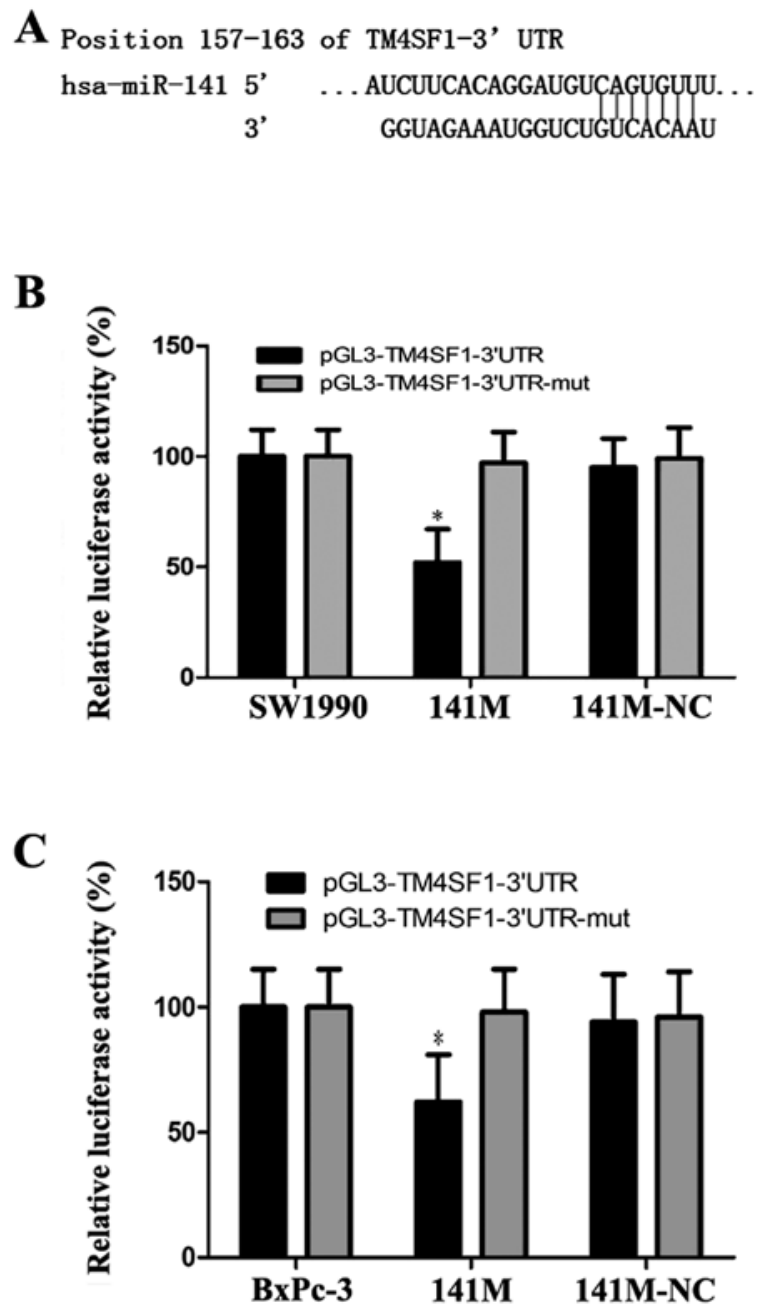

Figure 3. hsa-miR-141 directly targets TM4SF1. (A) The binding site of miR-141 in the 3'UTR region of TM4SF1 was predicted by TargetScan. (B and C) SW1990 and BxPc-3 cells transfected with the pGL3-TM4SF1 reporter vector together with $141 \mathrm{M}$ led to significantly reduced luciferase activity. The data were normalized by the ratio of Renilla luciferase activities. ${ }^{\text {}} \mathrm{P}<0.05$.

an MTT kit (Keygen) following the manufacturer's instructions daily for 5 days. Briefly, $20 \mu \mathrm{l}$ of MTT solution $(5 \mathrm{mg} / \mathrm{ml})$ was added to each well, cells were incubated for $4 \mathrm{~h}$ at $37^{\circ} \mathrm{C}$, then the medium in each well was replaced with $150 \mu$ l of dimethyl sulfoxide (DMSO), and the plate was oscillated for $10 \mathrm{~min}$. The optical density (OD) was detected by a microplate reader (Tecan, Shanghai, China) at $490 \mathrm{~nm}$ with $650 \mathrm{~nm}$ as a reference wavelength. Each assay was performed in triplicate and repeated independently three times.

Flow cytometry analysis of cell cycle progression and apoptosis. Cell cycle progression and apoptosis were assessed by flow cytometry (Becton-Dickinson, San Jose, CA, USA). SW1990 and BxPc-3 cells were grown and transfected with miRNAs. For cell cycle analysis, cells were collected and washed twice with PBS and fixed with $70 \%$ ethanol at $-20^{\circ} \mathrm{C}$ overnight. Cells were washed twice with PBS and resuspended in $500 \mu \mathrm{l}$ of PBS with $0.2 \%$ Triton X-100, $10 \mathrm{mM}$ EDTA, $100 \mu \mathrm{g} / \mathrm{ml} \mathrm{RNase} \mathrm{A}$, and $50 \mu \mathrm{g} / \mathrm{ml}$ propidium iodide (PI). The samples were incubated at room temperature for $30 \mathrm{~min}$. For apoptosis, cells were collected and washed twice with PBS, suspended in $100 \mu \mathrm{l}$ of $1 \mathrm{X}$ binding buffer, and stained with $5 \mu \mathrm{l}$ of Annexin V fluorescein isothiocyanate (FITC) and $5 \mu \mathrm{l}$ of PI at room temperature for $15 \mathrm{~min}$ in the dark. Then, the samples were analyzed by flow cytometry (Becton-Dickinson). All experiments were carried out in triplicate.

Statistical analysis. Each experiment was conducted at least three times. All data were expressed as mean \pm standard deviation (SD). Differences between each group were analyzed by a Student's t-test. Statistical analysis was performed with SPSS software (version 16.0, SPSS Inc., Chicago, IL, USA). P<0.05 was considered statistically significant.

\section{Results}

The TM4SF1 protein levelnegatively correlates with the hsa-miR141 level in PC cell lines. First, we examined the protein level of TM4SF1 in four PC cell lines (SW1990, PANC-1, BxPC-3 and CFPAC-1). Western blot analysis showed that the protein level of TM4SF1 was the highest in SW1990 cells and the lowest in BxPC-3 cells (Fig. 1A). However, qRT-PCR analysis showed that there was no significant relationship between TM4SF1 protein and mRNA levels (Fig. 1B). Notably, qRT-PCR analysis showed that the expression level of miR-141 was the highest in BxPc-3 cells and the lowest in SW1990 cells (Fig. 1C). These data suggest that the TM4SF1 protein level is negatively correlated with the hsa-miR-141 level in PC cells.

TM4SF1 is a target of hsa-miR-141 in PC cells. Next, we detected protein and mRNA expression levels of TM4SF1 in SW1990 and BxPc-3 cells transfected with miR-141 mimic (141M), miR-141 inhibitor (141I), or the corresponding negative control (141M-NC or 141I-NC). Western blot analysis showed that the TM4SF1 protein level was lower in the 141M group and higher in the 141I group (Fig. 2A and D), compared to the negative controls, respectively. In addition, the TM4SF1 protein level negatively correlated with the hsa-miR-141 level $\left({ }^{*} \mathrm{P}<0.05\right.$, Fig. $2 \mathrm{C}$ and F). qRT-PCR analysis showed that there was no obvious change in the TM4SF1 mRNA level (Fig. 2B and E). These data indicate that miR-141 post-transcriptionally inhibits TM4SF1 expression.

To confirm that hsa-miR-141 directly targets the 3'UTR of the TM4SF1 gene, we used TargetScan to predict the 3'UTR of TM4SF1 and the binding site of miR-141 (Fig. 3A). Based on this program, we generated pGL3-TM4SF1 and pGL3-TM4SF1mut vectors as the luciferase reporter and control, respectively, and transfected them into SW1990 and BxPc-3 cells, together with $141 \mathrm{M}$ or $141 \mathrm{M}-\mathrm{NC}$. The luciferase assay showed that luciferase activity was approximately $48 \%$ and $43 \%$ less in the $141 \mathrm{M}$ group compared with the control ("P<0.05, Fig. $3 \mathrm{~B}$ and C). These results suggest that miR-141 directly targets TM4SF1 via the binding site in its 3'UTR region.

hsa-miR-141 inhibits invasion and migration of PC cells in vitro. Matrigel invasion and Transwell assays were used to detect the effects of hsa-miR-141 on the invasion and migration of SW1990 and BxPc-3 cells in vitro. As shown in Fig. 4A, B, $\mathrm{E}$ and $\mathrm{F}$, transfection with 141I could promote invasion, while $141 \mathrm{M}$ inhibited invasion of SW1990 and BxPc-3 cells $(\mathrm{P}<0.05)$. Similarly, as shown in Fig. 4C, D, G and H, transfection with 


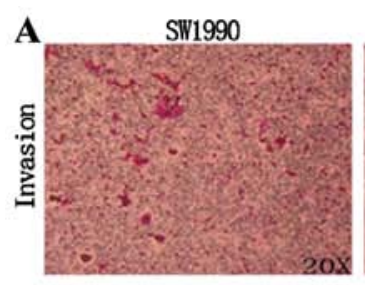

\section{B}

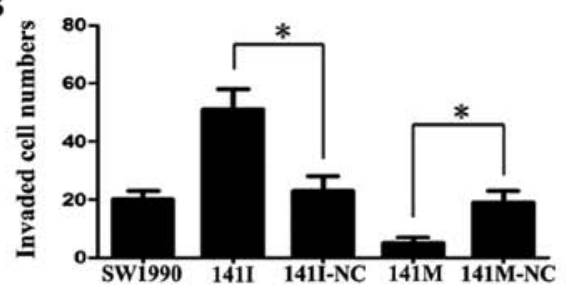

$141 \mathrm{I}$

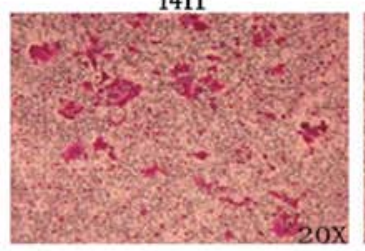

$20 x$
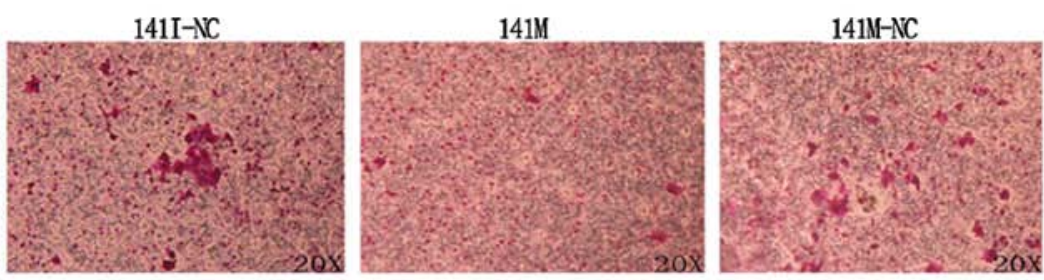

\section{C}
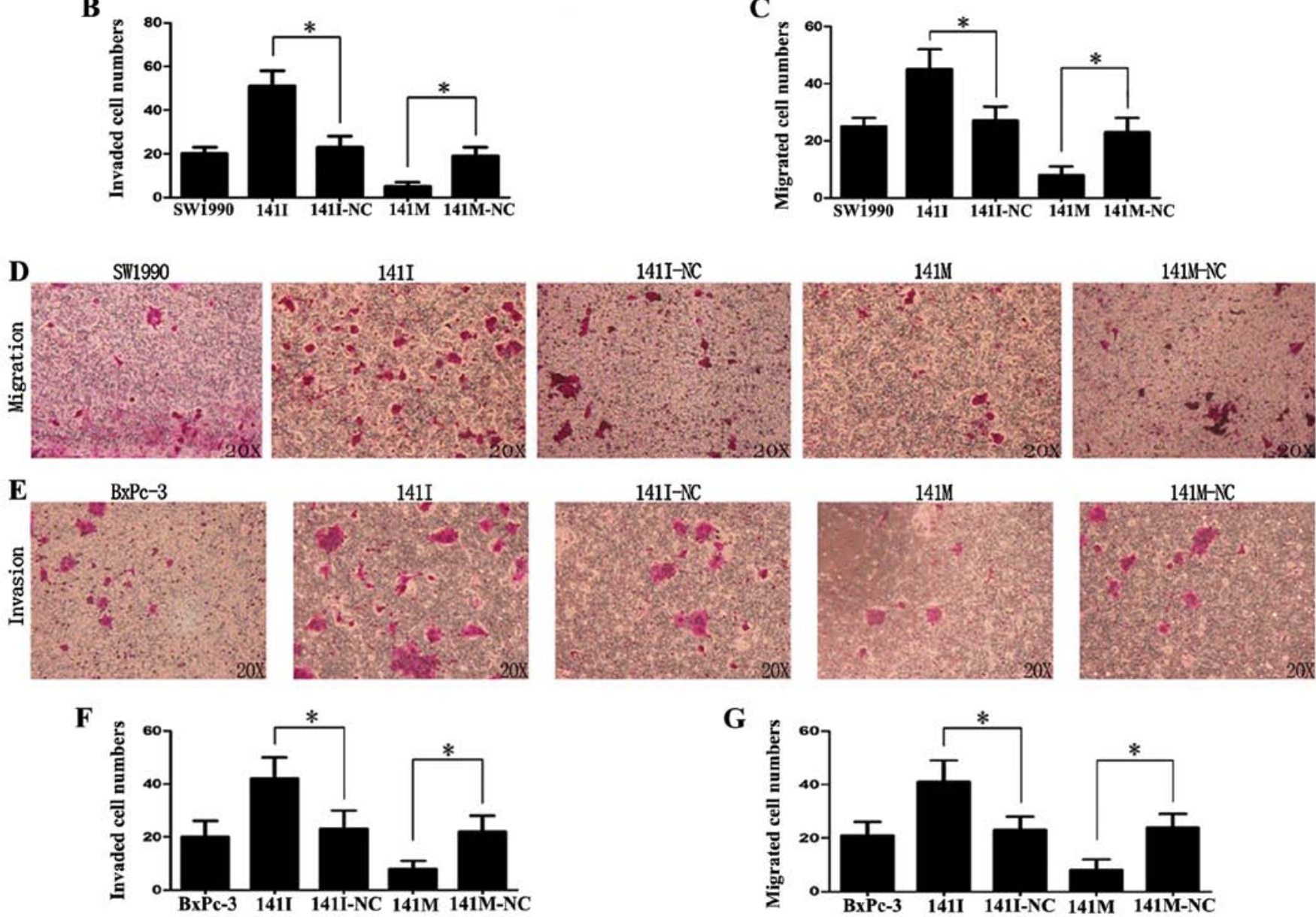

G
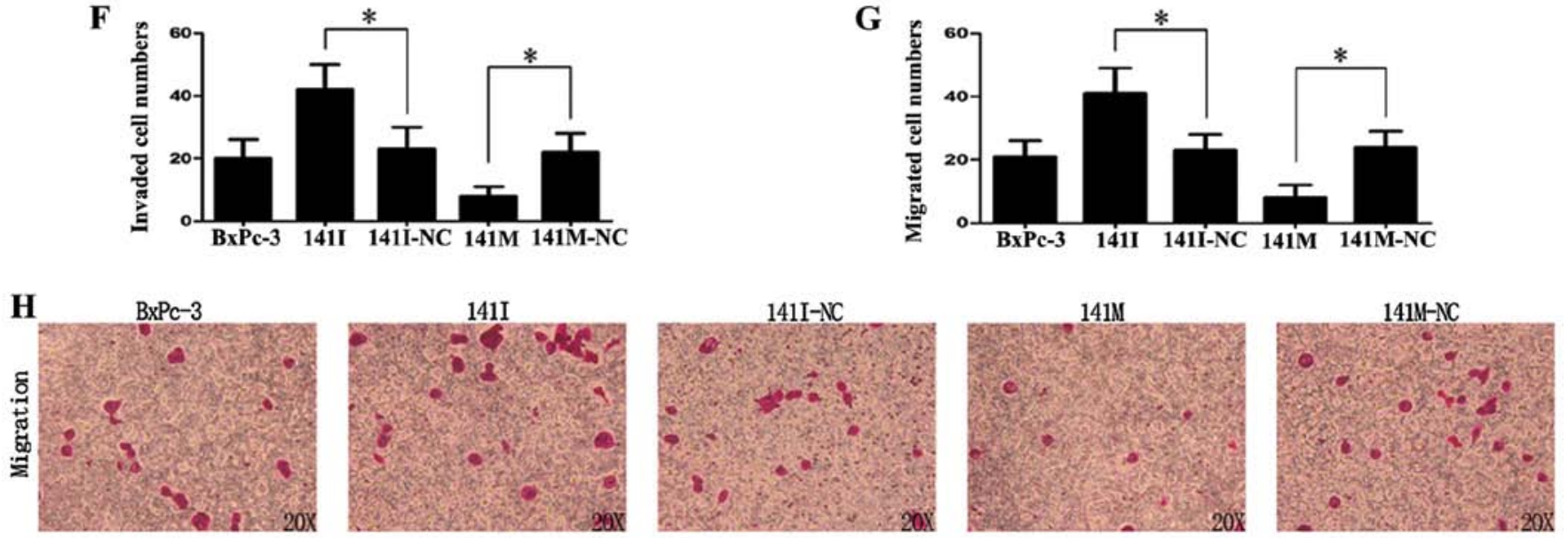

Figure 4. miR-141 inhibits the invasion and migration of SW1990 and BxPc-3 cells. (A, D, E and H) Representative photographs of invading or migrating cells. ( $\mathrm{B}$ and $\mathrm{F}$ ) The number of invading cells from three independent experiments ( $\mathrm{P}<0.05)$. ( $\mathrm{C}$ and $\mathrm{G})$ The number of migrating cells from three independent experiments $($ ( $\mathrm{P}<0.05)$.

141I could promote migration, while $141 \mathrm{M}$ could inhibit migration of SW1990 and BxPc-3 cells $(\mathrm{P}<0.05)$. These data suggest that hsa-miR-141 was able to inhibit invasion and migration of PC cells in vitro.

miR-141 has no effects on proliferation, cell cycle progression, and apoptosis of PC cells in vitro. To clarify whether hsa-miR141 could affect cell proliferation, cell cycle progression, or apoptosis in SW1990 and BxPc-3 cells, we performed an MTT assay and found that transfection of $141 \mathrm{M}$ or $141 \mathrm{I}$ caused no significant difference in cell proliferation in each group (Fig. 5A and F). Flow cytometry analysis of cell cycle progression and apoptosis showed that the percentage of cells in the $\mathrm{S}+\mathrm{G} 2$ phase and the total apoptosis rate were not significantly different in each group (Fig. 5D, I, E and J).

\section{Discussion}

TM4SF1 is a member of the tetraspanin superfamily and was first described as a tumor-specific antigen in many human epithe- 
A

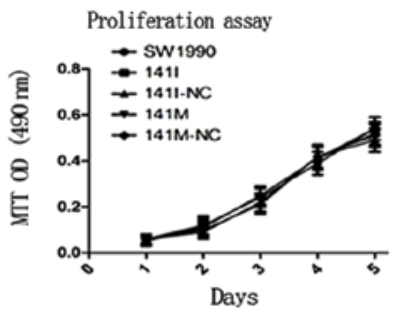

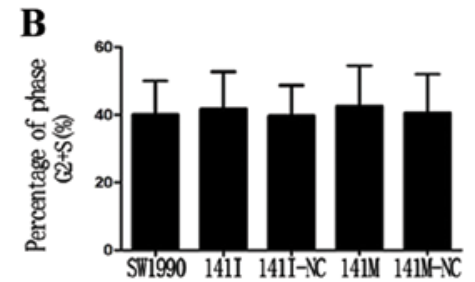

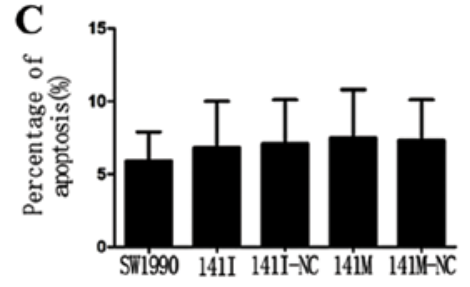

D
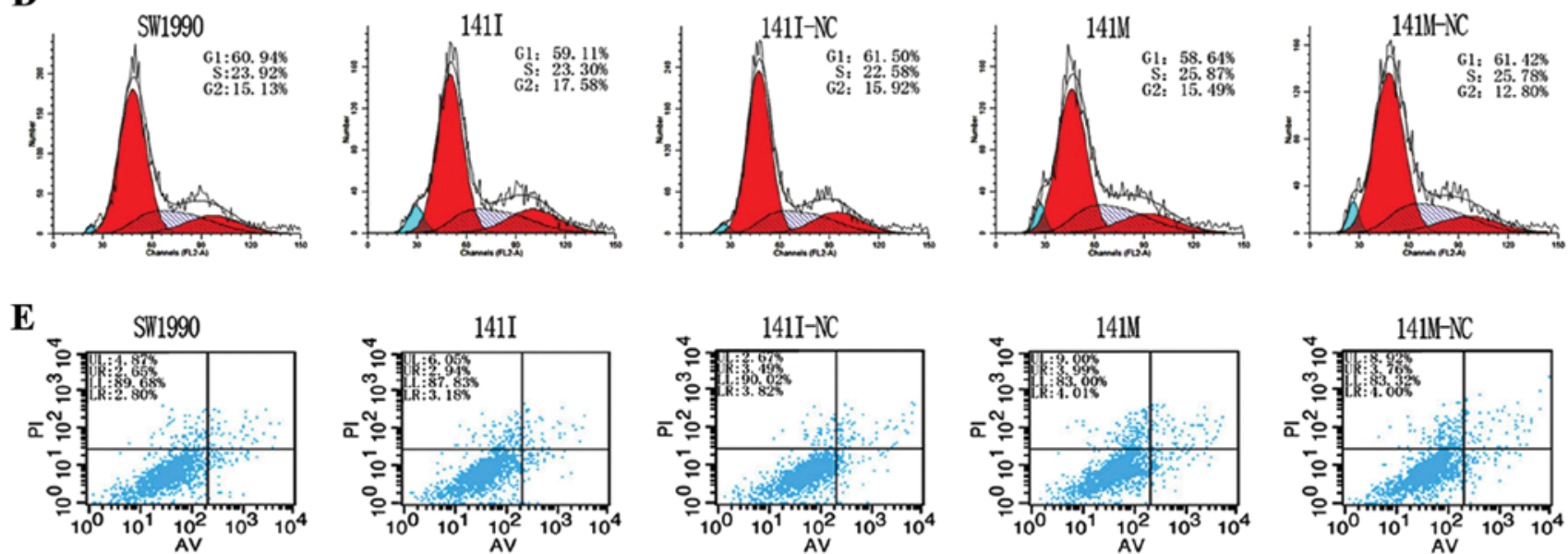

F Proliferation assay

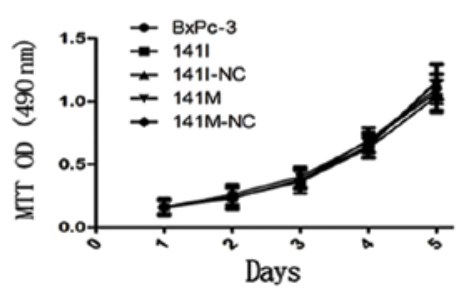

G

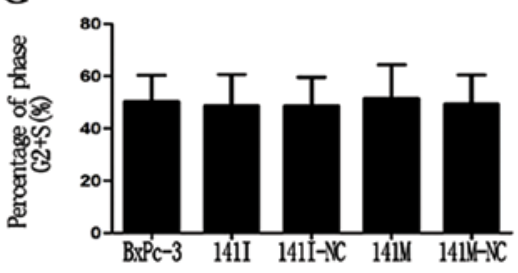

$\mathbf{H}$

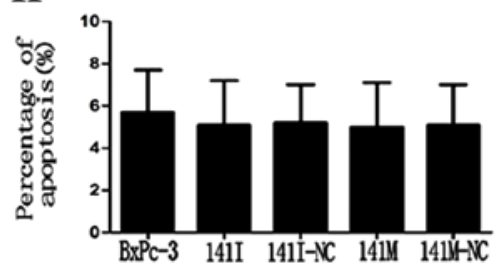

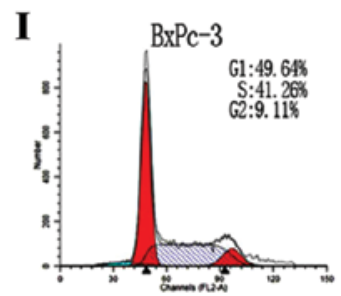
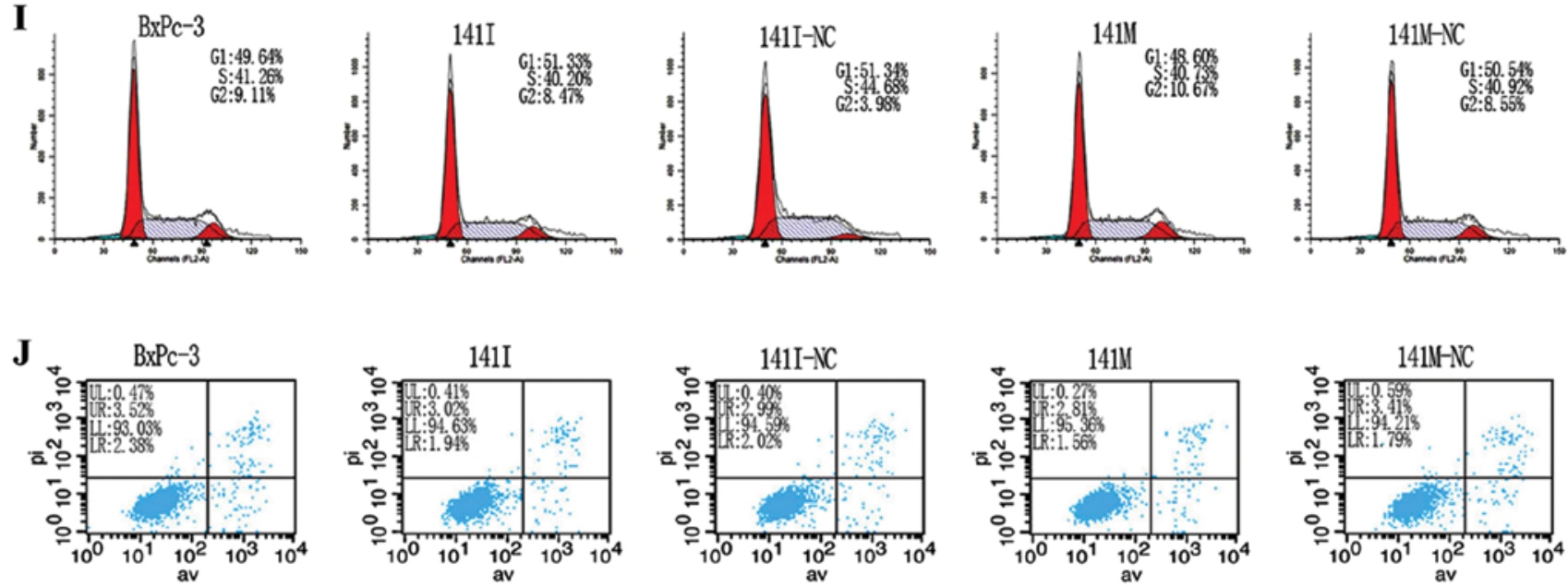

Figure 5. miR-141 has no obvious effects on proliferation, cell cycle progression, or apoptosis of SW1990 or BxPc-3 cells. SW1990 and BxPc-3 cells were transfected as indicated and then collected for the MTT assay and flow cytometry analysis. (A and F) The proliferation ability of SW1990 and BxPc-3 cells was detected by an MTT assay. (B, D, G and I) Cell cycle progression of SW1990 or BxPc-3 cells was measured by flow cytometry. (C, E, H and J) Apoptosis of SW1990 or BxPc-3 cells was monitored by flow cytometry. LR+UR is the total apoptosis rate.

lial malignancies such as lung, breast, colon, ovarian, renal and prostate carcinomas $(2,4)$. Janes and Watt found that TM4SF1 could interact with integrin family members to form transmem- brane complexes that affect cell adhesion, migration and tumor metastasis (29). TM4SF1 is overexpressed in the endothelium of human cancers, and it has been proposed that TM4SF1 acts as a 
'molecular organizer' to facilitate the gathering of specific cell surface proteins and the formation and stability of functional signaling complexes in tumor angiogenesis $(30,31)$.

The specific mechanism by which TM4SF1 is overexpressed in epithelial tumors remains unclear. By using TargetScan, we predicted that hsa-miR-141 could target TM4SF1 and regulate its expression. First, we detected the levels of TM4SF1 and hsa-miR-141 in four PC cell lines and found that TM4SF1 protein levels negatively correlated with hsa-miR-141 levels in different PC cell lines. Furthermore, western blot analysis showed that the TM4SF1 protein level was lower in the miR-141 mimic group and higher in the miR-141 inhibitor group, compared to the negative controls, respectively. Importantly, in these cells the TM4SF1 protein level but not the TM4SF1 mRNA level negatively correlated with the hsa-miR-141 level. These data suggest that hsa-miR-141 downregulates TM4SF1 expression at the post-transcriptional level. Next, we performed a luciferase assay and provided evidence that TM4SF1 is a direct target gene of hsa-miR-141.

hsa-miR-141 belongs to the miR-200 family, which consists of the following members: miR-141, miR-200a, miR-200b, miR-200c and miR-429 (32). Overexpression of hsa-miR-141 has been shown to inhibit invasion and migration of breast cancer, colorectal cancer and pancreatic cancer (33-35). Consistent with these previous studies, in this study we employed Matrigel invasion and Transwell migration assays to demonstrate that the miR-141 mimic resulted in a significant decrease of cell invasion and migration, while the miR-141 inhibitor led to a significant increase of cell invasion and migration. Given the crucial role of the cell surface protein TM4SF1 in tumor invasion and metastasis (29), it is reasonable to expect that miR-141 could directly target and downregulate the expression of TM4SF1, leading to loss of oncogenic function of TM4SF1. Our findings satisfactorily explain the downregulation of miR-141 and overexpression of TM4SF1 in $\mathrm{PC}$ and support current opinions that TM4SF1 is an oncoprotein and that miR-141 is a tumor-suppressive miRNA.

Notably, the effects of hsa-miR-141 on cancer cell proliferation have been studied, but the role of hsa-miR-141 in cell proliferation of different cancers is controversial. The miR-200 family has been reported to be overexpressed in pancreatic ductal adenocarcinoma (PDAC) cells and enhance cell proliferation (21). Similar results have been reported in cholangiocarcinoma, ovarian carcinoma and choriocarcinoma $(24,36,37)$. However, overexpression of hsa-miR-141 can significantly inhibit the proliferation of gastric cancer cells (26). In this study, we performed an MTT assay and flow cytometry analysis and found that miR-141 had no obvious effects on cell proliferation, cell cycle progression, or apoptosis in our experimental settings. SW1990 and BxPC-3 cells are derived from pancreatic adenocarcinoma, while CFPAC and PANC-1 cells originate from PDAC. The different sources of PC cells may lead to different results with regard to the role of hsa-miR-141 in the regulation of cell proliferation and apoptosis. Further studies that employ a variety of different PC cell lines and in vivo xenograft mouse models will help clarify the controversial results.

In conclusion, in this study we showed that the miR-141 level negatively correlated with TM4SF1 protein in PC cells. By using gain and loss of function approaches, we demonstrated that miR-141 downregulated TM4SF1 expression to inhibit the metastatic potential of PC cells but had no effects on cell proliferation, cell cycle progression or apoptosis. Furthermore, for the first time, we identified TM4SF1 as a direct target of miR-141. Our findings that TM4SF1 expression is inhibited by miR-141 provide new insight into the oncogenic function mechanism of TM4SF1 and suggest that miR-141 represents a novel molecular target for PC therapy.

\section{Acknowledgements}

This study was supported by the National Nature Science Foundation of China (Nos. 81170336 and 81272239) and the Research Special Fund for Public Welfare Industry of Health of China (201202007). We thank Medjaden Bioscience Limited for assisting in the preparation of this manuscript.

\section{References}

1. Siegel R, Naishadham D and Jemal A: Cancer statistics, 2012. CA Cancer J Clin 62: 10-29, 2012.

2. Wright MD, Ni J and Rudy GB: The L6 membrane proteins - a new four-transmembrane superfamily. Protein Sci 9: 1594-1600, 2000.

3. Allioli N, Vincent S, Vlaeminck-Guillem V, DecaussinPetrucci M, Ragage F, Ruffion A and Samarut J: TM4SF1, a novel primary androgen receptor target gene over-expressed in human prostate cancer and involved in cell migration. Prostate 71: 1239-1250, 2011.

4. Hellstrom I, Horn D, Linsley P, Brown JP, Brankovan V and Hellstrom KE: Monoclonal mouse antibodies raised against human lung carcinoma. Cancer Res 46: 3917-3923, 1986.

5. Chang YW, Chen SC, Cheng EC, Ko YP, Lin YC, Kao YR, Tsay YG, Yang PC, Wu CW and Roffler SR: CD13 (aminopeptidase N) can associate with tumor-associated antigen L6 and enhance the motility of human lung cancer cells. Int J Cancer 116: 243-252, 2005.

6. Lekishvili T, Fromm E, Mujoomdar M and Berditchevski F: The tumour-associated antigen L6 (L6-Ag) is recruited to the tetraspanin-enriched microdomains: implication for tumour cell motility. J Cell Sci 121: 685-694, 2008.

7. Kao YR, Shih JY, Wen WC, Ko YP, Chen BM, Chan YL, Chu YW, Yang PC, Wu CW and Roffler SR: Tumor-associated antigen L6 and the invasion of human lung cancer cells. Clin Cancer Res 9: 2807-2816, 2003.

8. Cao J, Ramachandran V, Arumugam T, Nast F and Logsdon C: TM4SF1 stimulates pancreatic cancer cell migration and invasion. Pancreas 38: 986, 2009.

9. Ying SY, Chang DC and Lin SL: The microRNA (miRNA): overview of the RNA genes that modulate gene function. Mol Biotechnol 38: 257-268, 2008.

10. Wang F, Xue X, Wei J, An Y, Yao J, Cai H, Wu J, Dai C, Qian Z, $\mathrm{Xu} \mathrm{Z}$ and Miao Y: hsa-miR-520h downregulates ABCG2 in pancreatic cancer cells to inhibit migration, invasion, and side populations. Br J Cancer 103: 567-574, 2010.

11. Aguda BD, Kim Y, Piper-Hunter MG, Friedman A and Marsh CB: MicroRNA regulation of a cancer network: consequences of the feedback loops involving miR-17-92, E2F, and Myc. Proc Natl Acad Sci USA 105: 19678-19683, 2008.

12. Grady WM, Parkin RK, Mitchell PS, Lee JH, Kim YH, Tsuchiya KD, Washington MK, Paraskeva C, Willson JK, Kaz AM, Kroh EM, Allen A, Fritz BR, Markowitz SD and Tewari M: Epigenetic silencing of the intronic microRNA hsa-miR-342 and its host gene EVL in colorectal cancer. Oncogene 27: 3880-3888, 2008.

13. Furuta M, Kozaki KI, Tanaka S, Arii S, Imoto I and Inazawa J: miR-124 and miR-203 are epigenetically silenced tumor-suppressive microRNAs in hepatocellular carcinoma. Carcinogenesis 31: 766-776, 2010.

14. Gandellini P, Folini M, Longoni N, Pennati M, Binda M, Colecchia M, Salvioni R, Supino R, Moretti R, Limonta P, Valdagni R, Daidone MG and Zaffaroni N: miR-205 exerts tumor-suppressive functions in human prostate through down-regulation of protein kinase Cepsilon. Cancer Res 69: 2287-2295, 2009. 
15. Hoffman AE, Zheng T, Yi C, Leaderer D, Weidhaas J, Slack F, Zhang Y, Paranjape T and Zhu Y: microRNA miR-196a-2 and breast cancer: a genetic and epigenetic association study and functional analysis. Cancer Res 69: 5970-5977, 2009.

16. Lee KH, Chen YL, Yeh SD, Hsiao M, Lin JT, Goan YG and Lu PJ: MicroRNA-330 acts as tumor suppressor and induces apoptosis of prostate cancer cells through E2F1-mediated suppression of Akt phosphorylation. Oncogene 28: 3360-3370, 2009.

17. Aqeilan RI, Calin GA and Croce CM: miR-15a and miR-16-1 in cancer: discovery, function and future perspectives. Cell Death Differ 17: 215-220, 2010

18. Iorio MV, Visone R, Di Leva G, Donati V, Petrocca F, Casalini P, Taccioli C, Volinia S, Liu CG, Alder H, Calin GA, Menard S and Croce CM: MicroRNA signatures in human ovarian cancer. Cancer Res 67: 8699-8707, 2007.

19. Bandres E, Cubedo E, Agirre X, Malumbres R, Zarate R Ramirez N, Abajo A, Navarro A, Moreno I, Monzo M and Garcia-Foncillas J: Identification by Real-time PCR of 13 mature microRNAs differentially expressed in colorectal cancer and non-tumoral tissues. Mol Cancer 5: 29, 2006.

20. Pallante P, Visone R, Ferracin M, Ferraro A, Berlingieri MT, Troncone G, Chiappetta G, Liu CG, Santoro M, Negrini M Croce CM and Fusco A: MicroRNA deregulation in human thyroid papillary carcinomas. Endocr Relat Cancer 13: 497-508, 2006.

21. Kent OA, Mullendore M, Wentzel EA, Lopez-Romero P Tan AC, Alvarez H, West K, Ochs MF, Hidalgo M, Arking DE, Maitra A and Mendell JT: A resource for analysis of microRNA expression and function in pancreatic ductal adenocarcinoma cells. Cancer Biol Ther 8: 2013-2024, 2009.

22. Zhang L, Deng T, Li X, Liu H, Zhou H, Ma J, Wu M, Zhou M, Shen S, Niu Z, Zhang W, Shi L, Xiang B, Lu J, Wang L, Li D, Tang $\mathrm{H}$ and Li G: microRNA-141 is involved in a nasopharyngeal carcinoma-related genes network. Carcinogenesis 31 : 559-566, 2010

23. Amaral FC, Torres N, Saggioro F, Neder L, Machado HR, Silva WA Jr, Moreira AC and Castro M: MicroRNAs differentially expressed in ACTH-secreting pituitary tumors. J Clin Endocrinol Metab 94: 320-323, 2009.

24. Meng F, Henson R, Lang M, Wehbe H, Maheshwari S, Mendell JT, Jiang J, Schmittgen TD and Patel T: Involvement of human micro-RNA in growth and response to chemotherapy in human cholangiocarcinoma cell lines. Gastroenterology 130 2113-2129, 2006.

25. Snowdon J, Zhang X, Childs T, Tron VA and Feilotter H: The microRNA-200 family is upregulated in endometrial carcinoma. PLoS One 6: e22828, 2011.

26. Du Y, Xu Y, Ding L, Yao H, Yu H, Zhou T and Si J: Down-regulation of miR-141 in gastric cancer and its involvement in cell growth. J Gastroenterol 44: 556-561, 2009.
27. Nakada C, Matsuura K, Tsukamoto $Y$, Tanigawa $M$, Yoshimoto T, Narimatsu T, Nguyen LT, Hijiya N, Uchida T, Sato F, Mimata H, Seto M and Moriyama M: Genome-wide microRNA expression profiling in renal cell carcinoma: significant down-regulation of miR-141 and miR-200c. J Pathol 216: 418-427, 2008.

28. Gregory PA, Bert AG, Paterson EL, Barry SC, Tsykin A, Farshid G, Vadas MA, Khew-Goodall Y and Goodall GJ: The miR-200 family and miR-205 regulate epithelial to mesenchymal transition by targeting ZEB1 and SIP1. Nat Cell Biol 10: 593-601, 2008.

29. Janes SM and Watt FM: New roles for integrins in squamouscell carcinoma. Nat Rev Cancer 6: 175-183, 2006.

30. Shih SC, Zukauskas A, Li D, Liu G, Ang LH, Nagy JA, Brown LF and Dvorak HF: The L6 protein TM4SF1 is critical for endothelial cell function and tumor angiogenesis. Cancer Res 69: 3272-3277, 2009.

31. Maecker HT, Todd SC and Levy S: The tetraspanin superfamily: molecular facilitators. FASEB J 11: 428-442, 1997.

32. Baffa R, Fassan M, Volinia S, O'Hara B, Liu CG, Palazzo JP, Gardiman M, Rugge M, Gomella LG, Croce CM and Rosenberg A: MicroRNA expression profiling of human metastatic cancers identifies cancer gene targets. J Pathol 219: 214-221, 2009

33. Neves R, Scheel C, Weinhold S, Honisch E, Iwaniuk KM, Trompeter HI, Niederacher D, Wernet P, Santourlidis S and Uhrberg M: Role of DNA methylation in miR-200c/141 cluster silencing in invasive breast cancer cells. BMC Res Notes 3: 219, 2010.

34. Hu M, Xia M, Chen X, Lin Z, Xu Y, Ma Y and Su L: MicroRNA-141 regulates Smad interacting protein 1 (SIP1) and inhibits migration and invasion of colorectal cancer cells. Dig Dis Sci 55: 2365-2372, 2010.

35. Burk U, Schubert J, Wellner U, Schmalhofer O, Vincan E, Spaderna $S$ and Brabletz T: A reciprocal repression between ZEB1 and members of the miR-200 family promotes EMT and invasion in cancer cells. EMBO Rep 9: 582-589, 2008.

36. Mateescu B, Batista L, Cardon M, Gruosso T, de Feraudy Y, Mariani O, Nicolas A, Meyniel JP, Cottu P, Sastre-Garau X and Mechta-Grigoriou F: miR-141 and miR-200a act on ovarian tumorigenesis by controlling oxidative stress response. Nat Med 17: 1627-1635, 2011.

37. Morales-Prieto DM, Schleussner E and Markert UR: Reduction in miR-141 is induced by leukemia inhibitory factor and inhibits proliferation in choriocarcinoma cell line JEG-3. Am J Reprod Immunol 66 (Suppl 1): 57-62, 2011. 